\title{
Interaction of Fertility Level with Harvest Date and Frequency on Productiveness of Mixed Prairie
}

\section{RUSSELL J. LORENZ AND GEORGE A. ROGLER}

Highlight: Management practices are needed which will insure sustained production from fertilized mixed prairie. Prior to establishing grazing management practices, a better understanding of $N$ and $P$ fertilizer effects on the vegetation is needed. The interaction of harvest date and frequency with annual applications of $N$ and $P$ was studied over an 8-year period near Mandan, N. Dak. Yield increases were significant when $40 \mathrm{lb}$. N/acre (40-N) and 80-N were applied, but application of $160-N$ produced little or no increase over the yield from 80-N. Average yields were 548, 1,298, 1,875 and 1,908 lb./acre for the $0-, 40-, 80-$ and 160- $N$ levels, respectively. Without $N$, response to $P$ was small and generally not significant. When $N$ was applied annually, response to $P$ became significant in the fourth and subsequent years. Yields at all fertilizer levels decreased as frequency of harvest increased. Greatest yield reductions occurred when the sequence included harvest in June.

The effects of $\mathrm{N}$ and $\mathrm{P}$ fertilizer on native grasslands have often been studied by measuring residual response over a period of years following a single application of fertilizer. Results from studies in the northern Great Plains of the United States and southwestern Canada have been varied. Less than $30 \mathrm{lb}$. elemental $\mathrm{N} /$ acre $(30-\mathrm{N})$ did not significantly increase dry matter production (Lodge,

The authors are research agronomists with the Plant Science Research Division, Agricultural Research Service, U. S. Department of Agriculture, U. S. Northern Great Plains Research Center, Mandan, North Dakota.

Contribution of the Plant Science Research Division, Agr. Res. Serv., U. S. Dep. Agr., Mandan, N. D.

Manuscript received December 31, 1971.
1959) while higher rates occasionally did (Cosper and Thomas, 1961; Cosper et al., 1967; Smika et al., 1963; Kilcher et al., 1965; and Black, 1968) and rates greater than 60-N often did (Smoliak, 1965; Westin et al., 1955; and Mason and Miltimore, 1969). In many cases, the increase in production from single applications was not sufficient to be of economic value, but the fact that some increase in production did occur aroused interest in further study of fertilizer on mixed prairie.

Favorable results have been obtained from repeated annual applications of $\mathrm{N}$ to native grasslands. Westin et al. (1955) reported increased yields from application of $20-, 40-$ and $80-\mathrm{N}$ when applied to 
plot areas in pastures that had been grazed at heavy, moderate, and light intensities for the previous 10 years at the Range Field Station near Cottonwood, S. Dak. The greatest response was from 80-N applied annually to plots in the heavily grazed pasture. Most of the yield increase was attributed to $\mathrm{N}$, although annual application of $\mathrm{N}$ over a 3-year period resulted in response to $P$. Highly significant yield increases were also reported by Rogler and Lorenz (1957) from a study near Mandan, N. Dak. Over a 6-year period, yields were doubled by annual application of $30-\mathrm{N}$ and tripled by 90-N. In a companion study, Smika et al. (1965) found that water use efficiency (lb. forage produced/inch of water used) was increased as rates of fertilizer $\mathrm{N}$ were increased. They found that fertilized grass used 1.5 inches more water but produced three times more forage than did nonfertilized grass. Black (1968) found that $\mathrm{N}$ plus $\mathrm{P}$ fertilizer consistently increased forage yields of mixed prairie in eastern Montana and that water use efficiency was increased 1.5- to 2.5-fold.

The effect of clipping frequency and date of harvest on productivity of mixed prairie has also been studied. However, little is known of the effect of these treatments when fertilizer is included in the management system. Sarvis (1923) found the period of most active growth and of greatest forage production to be in May and June, the period in which livestock grazing mixed prairie make their greatest gains. He also found that total production was greatly reduced as clipping frequency increased.

The interaction of harvest variables with annual fertilizer application over a period of years was the major objective of the study reported herein.

\section{Study Area and Procedure}

The study area was selected for uniformity of topography, slope, and vegetative cover on a nearly level site located on the Missouri Plateau west of the Missouri River near Mandan, N. D. The soil series is Temvik, a well-drained chestnut soil formed from about 24 inches of calcareous silt-loam loess over clay-loam glacial till. The loess layer has a $\mathrm{pH}$ of 6.6 at the surface and 7.0 at the 24-inch depth. The glacial till has a $\mathrm{pH}$ of 8.0 to the 6-foot depth. The 0-6 and 6-12 inch increments of the loess layer contain 0.266 and $0.147 \%$ total $\mathrm{N}$, respectively. Sodium bicarbonate soluble $P$ content of this soil was found to be $11 \mathrm{lb}$./acre in the surface 6 inches and about $5 \mathrm{lb}$./acre in each of the next three 6-inch-depth increments.
Sarvis (1920) described the mixed prairie vegetation of the experimental area. He listed blue grama (Bouteloua gracilis [H.B.K.] Lag.), needleandthread (Stipa comata Trin. \& Rupr.), threadleaf sedge (Carex filifolia Nutt.), and sun sedge (Carex heliophila Mack.) as the dominant species with western wheatgrass (Agropyron smithii Rydb.), prairie junegrass (Koeleria cristata [L] Pers.), and fringed sage (Artemisia frigida Willd.) as the primary species. Species composition changed somewhat in the following 30 years, according to Rogler (1951). He included western wheatgrass among the dominant species.

The study area is in what was originally a school section, cut for hay in the years prior to 1916. Since 1916 it has been part of the Northern Great Plains Research Center Grazing Studies with a grazing intensity of light to moderate through the years.

The 1915-1970 average annual precipitation at the Northern Great Plains Research Center is 15.88 inches and the average annual growing season (AprilAugust) precipitation is 11.25 inches. Annual precipitation averaged 15.39 inches, and seasonal precipitation averaged 11.98 inches during the period of this study (1958-1965). Seasonal precipitation was near the long-time avcrage each year during this period, except for two unusually dry years, 1959 and 1961 , with 7.06 and 7.19 inches, respectively. In 1960, high intensity showers on May 25 (1.63 inches) and on June 19 (3.96 inches) resulted not only in above-average seasonal precipitation (13.75 inches) but also in excessive runoff, which reduced the effective precipitation to less than average for that year. The 1962 seasonal precipitation was 1.41 inches less than in 1960 , but it came as gentle effective showers distributed well through the season. Thus, 1962 was one of the best grass-producing seasons on record. Precipitation was slightly above average in 1963 and 1964, and far above average (23.34 inches annual) in 1965, also one of the best years on record. However, distribution through the season was not as good as in 1962, which resulted in lower total grass production than in 1962.

The study was initiated in the fall of 1957, using a randomized block replicated three times. Fertilizer treatments included $0-, 40-, 80-$ and $160-\mathrm{N}$ without $\mathrm{P}$, and $0-\mathrm{N}$ and $80-\mathrm{N}$ each with 18-P (0-18 and 80-18). Fertilizer was applied on November 3, 1957, and about midOctober each year thereafter through 1964. Ammonium nitrate was the source of $\mathrm{N}$, and treble superphosphate was the source of $\mathbf{P}$.

The effect of annual fertilizer application on dry matter production of mixed prairie vegetation was evaluated by harvesting seven sets of plots in turn each year. One set was harvested on the first and another on the 15th of each month, starting with May 1 and concluding with August 1. Plots harvested prior to July 1 were harvested again on August 1, providing a two-harvest frequency. Those harvested on July 1 and later were harvested only once each year. An eighth set was harvested on June 1, July 1, and August 1, which provided a three-harvest frequency.

Plot size was 6 by $20 \mathrm{ft}$ and a 3- by $20-\mathrm{ft}$ swath was cut with a sickle-bar mower on prescribed harvest dates. The mower was equipped with metal shoes which provided about a 1-inch height of cut.

\section{Results and Discussion Fertilizer Response}

The average dry matter yields for each of the fertilizer treatments for each year of the study are presented in Table 1 . These values are the average season total yields of all harvest dates and frequencies for each fertilizer treatment and can be used to compare response to fertilizer within each year and over the 8-year pcriod. Annual application of 40-N produced a highly significant $(\mathrm{P}<0.01)$ yield increase over the yields of plots receiving no $\mathrm{N}$ or $\mathrm{P}(0-0)$ or no $\mathrm{N}$ with 18-P (0-18). Application of 80-N always produced a highly significant yield increase over the yield of plots receiving 40-N. However, application of $160-\mathrm{N}$ did not produce a proportionate yield increase. Only in $1958 \mathrm{did} 160-\mathrm{N}$ produce a significant yield increase over the $80-0$ and the 80-18 treatments.

Application of $\mathrm{P}$ without $\mathrm{N}$ did not produce significant yield increases, and differences in yield between plots receiving the 80-0 and 80-18 treatments were not significant in 1958 and 1959. However, in each year after 1959, and for the 8-year period, the addition of 18-P with $80-\mathrm{N}$ resulted in significant yield increases over those from plots receiving 80-N alone. Each year after 1959 and for the 8 -year averages, plots receiving the 80-18 treatment produced significantly more than did those receiving the $160-0$ treatment. The response to $\mathrm{P}$ at the $80-\mathrm{N}$ level suggests that perhaps plots receiving the 160-N treatment would have also benefited from application of P. Under the conditions of this study, it is evident that after a few years of increased production through the use of $\mathrm{N}$, application of $\mathbf{P}$ will also be necessary to obtain optimum yields.

It is of particular importance that even 
during the dry years of 1959 and 1961, significant yield increases occurred with increasing levels of $\mathrm{N}$ and $\mathrm{P}$. Although the actual yield increase was small during these dry years, an increase of only a few hundred lb./acre may be more valuable to the livestock enterprise in a dry year than would several hundred $\mathrm{lb}$. in a year of better moisture conditions.

\section{Harvest Date}

Forage removal by mowing on prescribed dates or combination of dates provided the yield data shown in Table 2 . Depending upon moisture conditions, year-to-year variation in yield was quite large. However, regardless of the magnitude of the yield in any particular year, some combinations of harvest dates reduced production. Total yield for the season decreased as date of first harvest was delayed by 15-day intervals from May 1 through June 15. Yields were greatest when forage was harvested only once each year on either July 15 or season was usually reached sometime after July 1 . In only 1 year out of 8 was maximum yield obtained by harvest on July 1 . In 3 of the 8 years, the yield on August 1 was significantly greater than it was on July 15 , indicating that maximum production may have been reached after August 1 in those 3 years.

Yields on each successive date of first harvest (May 1 through June 15) averaged 24, 139, 338 and $637 \mathrm{lb}$./acre for the 8 -year period. In 4 of the 8 years, there on May 1. Consequently, the major portion of the total yield was removed by the August 1 harvest of the May 1-August 1 harvest combination. This accounts for the similarity between yields from this harvest treatment and those of the single cuttings taken on either July 15 or August 1. Harvest on June 1 or June 15 and again on August 1 significantly reAugust 1. Maximum production for the was not enough growth to permit harvest

Table 2. Average total dry matter yield (lb./acre) of mixed prairie when harvested at 1-inch height on various combinations of dates in each of 8 years.

\begin{tabular}{lrrrrrrrrr}
\hline \hline & \multicolumn{7}{c}{ Dry matter } \\
\cline { 2 - 9 } Harvest dates & 1958 & 1959 & 1960 & 1961 & 1962 & 1963 & 1964 & 1965 & Avg \\
\hline May 1, Aug. 1 & 1553 & 361 & 1438 & 376 & 4184 & 1347 & 1805 & 2139 & 1650 \\
May 15, Aug. 1 & 1228 & 347 & 1264 & 313 & 3237 & 1122 & 1457 & 1842 & 1351 \\
June 1, Aug. 1 & 1027 & 304 & 1104 & 322 & 2897 & 1081 & 1493 & 1654 & 1235 \\
June 15, Aug. 1 & 1100 & 337 & 1049 & 345 & 2569 & 1049 & 1218 & 1577 & 1156 \\
July 1 & 1227 & 490 & 1213 & 306 & 2222 & 1566 & 987 & 1537 & 1194 \\
July 15 & 1598 & 521 & 1856 & 334 & 3416 & 1391 & 1834 & 1914 & 1608 \\
Aug. 1 & 1496 & 480 & 1621 & 416 & 4157 & 1356 & 1838 & 2180 & 1693 \\
Average & 1318 & 406 & 1364 & 345 & 3240 & 1273 & 1519 & 1835 & 1412 \\
LSD 1 0.05 & 146 & 64 & 201 & 42 & 271 & 106 & 147 & 162 & 91 \\
\multicolumn{1}{c}{0.01} & 194 & 85 & 267 & 55 & 360 & 141 & 195 & 215 & 121 \\
\hline
\end{tabular}

${ }_{1}$ Least significant difference.

duced total production for the season. Over the 8-year period, harvest on July 1 produced significantly less dry matter than did harvest on either July 15 or $\Lambda$ ugust 1.

The interaction of fertility level with harvest date over the 8-year period is shown in Fig. 1. Without $\mathrm{N}$, date of harvest had little effect on total yield, except for the May 1-August 1 combination and the single harvests on July 15 and August 1, each of which resulted in significantly greater production than did any of the other date-of-harvest treatments. When 40-N was applied, the magnitude of the date-of-harvest effect increased although the general pattern remained much the same as for $0-\mathrm{N}$. This trend continued for the $80-\mathrm{N}$ and $160-\mathrm{N}$ levels, but harvest on June 15-August 1 or on July 1 only reduced the total yield more than did harvest on May 15-August 1 or on June 1-August 1 at these N levels. Response to application of 18-P without $\mathrm{N}$ was not significant for any of the harvest dates, but when 18-P was applied with 80-N, yields on all dates were significantly increased. Evidently time of forage removal, either by mowing or grazing, will be of particular importance in obtaining maximum return from

Table 1. Dry matter yields (lb./acre) of mixed prairie vegetation under various fertilizer treatments (lb./acre) over an 8-year period when cut at 1-inch height.

\begin{tabular}{|c|c|c|c|c|c|c|c|c|c|}
\hline \multirow[b]{2}{*}{ N-P } & \multicolumn{9}{|c|}{ Dry matter } \\
\hline & 1958 & 1959 & 1960 & 1961 & 1962 & 1963 & 1964 & 1965 & Avg \\
\hline $0-0$ & 699 & 198 & 578 & 151 & 1201 & 486 & 477 & 598 & 548 \\
\hline $0-18$ & 747 & 218 & 598 & 166 & 1308 & 531 & 478 & 637 & 585 \\
\hline $40-0$ & 1032 & 383 & 1224 & 319 & 3083 & 1197 & 1362 & 1783 & 1298 \\
\hline $80-0$ & 1654 & 527 & 1807 & 408 & 4413 & 1670 & 2019 & 2501 & 1875 \\
\hline $80-18$ & 1706 & 579 & 2204 & 555 & 5324 & 2025 & 2637 & 3051 & 2260 \\
\hline $160-0$ & 2072 & 528 & 1771 & 472 & 4114 & 1730 & 2142 & 2438 & 1908 \\
\hline Average & 1318 & 406 & 1364 & 345 & 3240 & 1273 & 1519 & 1835 & 1412 \\
\hline $\mathrm{LSD}^{1} 0.05$ & 135 & 59 & 186 & 39 & 251 & 98 & 136 & 150 & 84 \\
\hline 0.01 & 180 & 78 & 247 & 51 & 333 & 130 & 181 & 199 & 112 \\
\hline
\end{tabular}

1 Least significant difference. fertilization.

\section{Harvest Frequency}

The effect of harvest frequency on dry matter production as influenced by $\mathrm{N}$ and $P$ levels was evaluated by comparison of the yields obtained on August 1 and from the June 1-August 1 combination with those from the June 1-July 1-August 1 harvest treatment. A summary by years of the yields for each of these three harvest frequencies is shown in Table 3. Yields decreased as harvest frequency increased each year, as well as over the 8-year period. Highly significant yield decreases occurred when forage was removed twice rather than once each season. Harvesting three times rather than twice each season further decreased yields, but not significantly during the first 4 years, 1958 through 1961. However, during the next 4 years and for the 8-year average, the yield decreases were highly significant. Over the 8-year period, average yield of the treatments harvested twice each year was $27 \%$ less and of the treatments harvested three times, $48 \%$ less than that of the treatments harvested only once each year.

The effect of the interaction of fertility level with harvest frequency on dry matter production is shown in Figure 2. Yield increase in response to $\mathrm{N}$ was highly significant for each harvest frequency in each year; however, yields decreased at each $\mathrm{N}$ level as harvest frequency increased. Removing the forage twice each season reduced dry matter yields to 73 , 76,75 and $71 \%$ of those from a single harvest on August 1, and harvesting three times reduced them to 61, 50, 47 and $52 \%$ for the 0-, 40-, 80- and 160-N levels, respectively. Response to $\mathrm{P}$ without $\mathrm{N}$ was small and generally not significant for each harvest frequency; however, with $80-\mathrm{N}, 18-\mathrm{P}$ of ten produced highly significant yield increases for all three harvest 


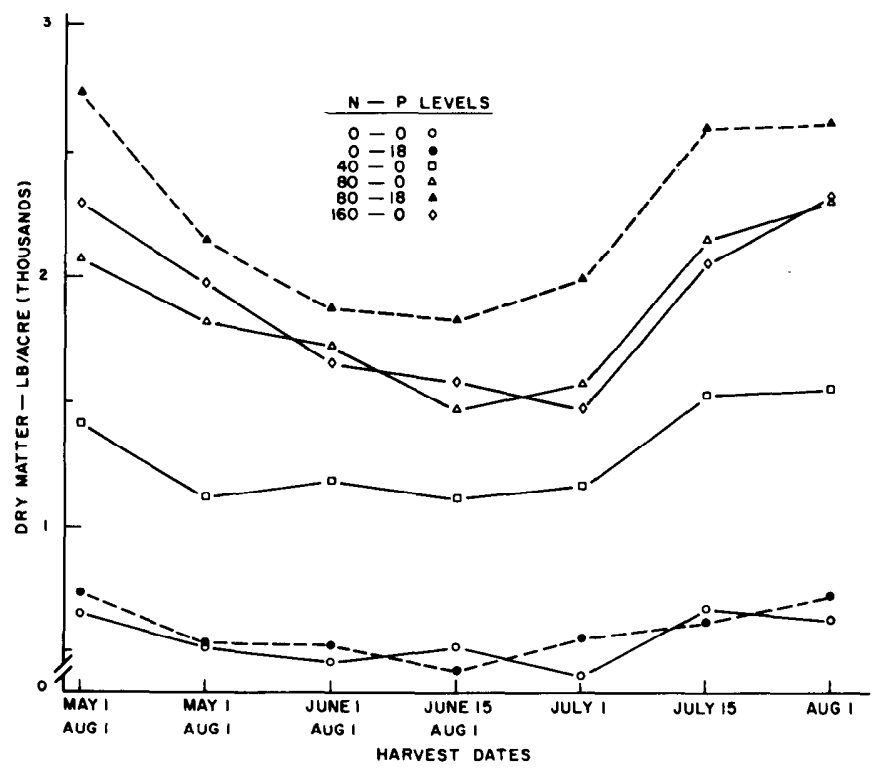

Fig. 1. Effect of fertility level and harvest date on average dry matter production of mixed prairie.

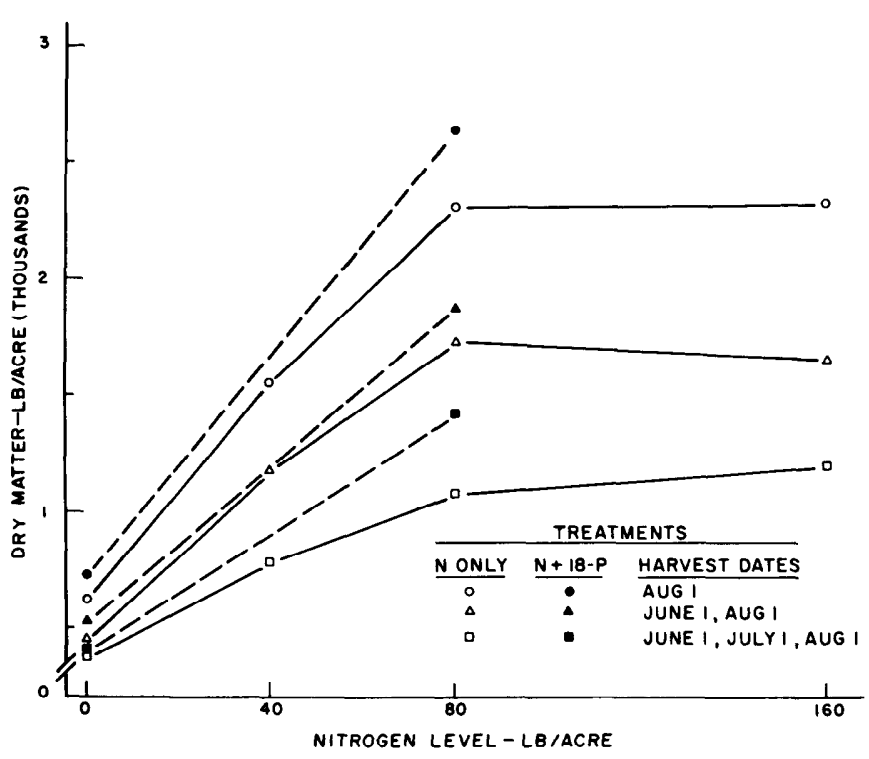

Fig. 2. Effect of fertility level and harvest frequency on average dry matter production of mixed prairie. frequencies.

Removal of all growth above 1 inch by mowing is a more severe treatment than is grazing at the proper intensity, but these data illustrate the detrimental effect of removal of a large portion of the growing plant material in June and July on total annual production of mixed prairie. The increase in growth rate early in the season following application of $\mathrm{N}$ would help keep forage production ahead of removal by livestock; however, judicious grazing management will be necessary to obtain the best return from the fertilizer applied. Clipping data are an indication of what can be expected; however, actual grazing trials will be necessary to establish suitable management practices for grazing fertilized mixed prairie.

\section{Summary}

Response of mixed prairie vegetation to annual applications of $\mathrm{N}$ and $\mathrm{P}$ fertilizers was studied during an 8-year period at the Northern Great Plains Research Center near Mandan, N. D. Fertilizer rates were $0-, 40-, 80-$ and $160-\mathrm{N}$ without $\mathrm{P}$ and $0-$ and 18-P with $0-$ and $80-\mathrm{N}$. Dry matter production was measured by mowing at a height of 1 inch on specific dates each year. Harvest dates were at 15-day intervals, beginning with May 1 and concluding with August 1. Plots harvested prior to July 1 were harvested again on August 1 which provided a two-harvest frequency. A third frequency of harvest was obtained by harvesting a set of plots on June 1, July 1 and August 1 of each year.

Significant increases in dry matter

Table 3. Annual dry matter yields (lb./acre) of mixed prairie for each of three harvest frequencies when cut at 1 -inch height in each of 8 years.

\begin{tabular}{|c|c|c|c|c|c|}
\hline \multirow[b]{4}{*}{ Year } & \multicolumn{5}{|c|}{ Dry matter } \\
\hline & \multicolumn{3}{|c|}{ Harvest dates } & & \\
\hline & \multirow[b]{2}{*}{ August 1} & \multirow{2}{*}{$\begin{array}{c}\text { June } 1 \\
\text { August } 1\end{array}$} & \multirow{2}{*}{$\begin{array}{c}\text { June } 1 \\
\text { July } 1 \\
\text { August } 1\end{array}$} & \multicolumn{2}{|c|}{$\mathrm{LSD}^{1}$} \\
\hline & & & & 0.05 & 0.01 \\
\hline 1958 & 1496 & 1027 & 901 & 144 & 194 \\
\hline 1959 & 480 & 304 & $305^{2}$ & 60 & 80 \\
\hline 1960 & 1621 & 1104 & 928 & 222 & 298 \\
\hline 1961 & 416 & 322 & 286 & 39 & 52 \\
\hline 1962 & 4157 & 2897 & 1676 & 267 & 357 \\
\hline 1963 & 1356 & 1081 & 896 & 98 & 131 \\
\hline 1964 & 1838 & 1493 & 950 & 134 & 179 \\
\hline 1965 & 2131 & 1654 & 1089 & 119 & 160 \\
\hline Average & 1687 & 1235 & 879 & 139 & 186 \\
\hline
\end{tabular}

${ }_{1}$ Least significant difference.

${ }^{2}$ Cut only twice in $1959, \mathrm{~J}$ une 1 and August 1 .

production were found for each of the first two increments of $\mathrm{N}$; however, plots receiving the third increment, 160-N, often produced no more than did those receiving $80-\mathrm{N}$. Over the 8 -year period, harvest at the 1 -inch height resulted in average annual yields of $548,1,298$, 1,875 and $1,908 \mathrm{lb}$./acre for the $0-, 40-$, 80- and 160-N levels, respectively.

Response to $\mathrm{P}$ was often not significant during the first 3 years of the study. However, over the 8-year period, 18-P applied with $80-\mathrm{N}$ resulted in highly significant yield increases over those from application of 80-N without P. Without $\mathrm{N}$, response to $\mathrm{P}$ was small and generally not significant.

Maximum production for the season was usually obtained on the July 15 harvest date. The plots harvested on August 1 often produced significantly less than did those harvested in July. In 4 out of the 8 years, there was not enough growth on May 1 to permit harvest. Consequently, the May 1-August 1 harvest combination resulted in yields similar to those from a single harvest on August 1 .

Harvesting two or three times each season significantly decreased yield when compared with a single harvest on either July 15 or August 1. Average annual production was $1,687,1,235$ and 879 lb./acre for the plots harvested one, two and three times each year, respectively. Response to fertilizer was highly significant for each harvest frequency, even though total yield was reduced by more frequent harvest. 


\section{Literature Cited}

Black, A. L. 1968. Nitrogen and phosphorus fertilization for production of crested wheatgrass and native grass in northeastern Montana. Agron. J. 60:213-216.

Cosper, H. R., and J. R. Thomas. 1961. Influence of supplemental run-off water and fertilizer on production and chemical composition of native forage. J. Range Manage. 14:292-297.

Cosper, H. R., J. R. Thomas, and A. Y. Alsayegh. 1967. Fertilization and its effect on range improvement in the Northern Great Plains. J. Range Manage. 20:216-222.

Kilcher, M. R., S. Smoliak, W. A. Hubbard, A. Johnston, A. T. H. Gross, and E. V. McCurdy. 1965. Effects of inorganic nitrogen and phosphorus fertilizers on selected sites of native grassland in western Canada. Can. J. Plant Sci. 45:229-237.

Lodge, R. W. 1959. Fertilization of native range in the Northern Great Plains. J. Range Manage. 12:277-279.

Mason, J. L., and J. E. Miltimore. 1969. Yield increases from nitrogen on native range in southern British Columbia. J. Range Manage. 22:128-131.

Rogler, G. A. 1951. A twenty-five year comparison of continuous and rotation grazing in the Northern Plains. J. Range Manage. $4: 35-41$.

Rogler, G. A., and R. J. Lorenz. 1957. Nitrogen fertilization of Northern Great Plains rangelands. J. Range Manage. 10:156-160.

Sarvis, J. T. 1920. Composition and density of the native vegetation in the vicinity of the Northern Great Plains Field Station. J. Agr. Res. 19:63-72.

Sarvis, J. T. 1923. Effects of different systems and intensities of grazing upon the native vegetation at the Northern Great Plains Field Station. U. S. Dep. Agr. Dep. Bull. No. 1170.

Smika, D. E., H. J. Haas, and G. A. Rogler. 1963. Native grass and crested wheatgrass production as influenced by fertilizer placement and weed control. J. Range Manage. 16:5-8.

Smika, D. E., H. J. Haas, and J. F. Power. 1965. Effects of moisture and nitrogen fertilizer on growth and water use by native grass. Agron. J. 57:483-486.

Smoliak, S. 1965. Effects of manure, straw and inorganic fertilizers on Northern Great Plains ranges. J. Range Manage. 18:11-15.

Westin, F. C., A. J. Buntley, and B. L. Brage. 1955. Soil and weather. In Agricultural Research, S. Dak. Agr. Exp. Sta. Circ. 116.

\section{3}

dues-including a subscription to the Journal of Range Management and Rangeman's News-are past due. If you have not yet paid your dues for 1973 , please do so as soon as possible. 